\title{
Pengembangan LKS Berbasis Guided Discovery Learning pada Materi Statistika Kelas VIII SMP
}

\author{
Faradila Nur Sabrina ${ }^{1}$, Rustanto Rahardi ${ }^{2}$ \\ 1, 2 Program Studi Pendidikan Matematika, Fakultas Matematika dan Ilmu Pengetahuan Alam, Universitas Negeri Malang, \\ J1. Semarang No. 5, Sumbersari, Malang, Indonesia \\ faradila.nur.1603116@students.um.ac.id.com
}

\begin{abstract}
The purpose of this research was to develop a valid, practical, and effective Statistics worksheet for students based on Guided Discovery Learning. This Research and Development (R\&D) research used Plomp model development and used validity, practically, and effectiveness test as the techniques of data analysis. The result of this research was a valid declared worksheet based on validity test by validator obtained $93,75 \%$. After validity test, the worksheet was tested on research subject and declared practical based on student response questionnaire obtained $82,15 \%$ and teacher response questionnaire obtained $93,31 \%$. The worksheet was declared effective based on the result of research subject's formative test, $80 \%$ of students's result were above KKM.
\end{abstract}

Keywords: Development, Student Worksheet, Guided Discovery Learning, Statistics

\begin{abstract}
Abstrak
Tujuan dari penelitian ini adalah untuk menghasilkan produk berupa LKS berbasis Guided Discovery Learning pada materi Statistika kelas VIII yang valid, praktis, dan efektif. Penelitian Research and Development (R\&D) ini menggunakan model pengembangan Plomp. Dalam penelitian pengembangan LKS ini menggunakan teknik analisis data hasil uji validitas, uji kepraktisan, dan uji keefektifan produk. Hasil dari penelitian ini adalah LKS yang dinyatakan valid berdasarkan uji validasi oleh validator dengan hasil 93,75\%. Setelah dilakukan uji validasi, LKS diujicobakan kepada subjek penelitian dan dinyatakan praktis berdasarkan hasil angket respon siswa yaitu $82,19 \%$ dan angket respon guru yaitu 93,31\%. LKS juga dinyatakan efektif berdasarkan hasil tes formatif subjek penelitian yaitu terdapat $80 \%$ siswa mendapat nilai di atas KKM.
\end{abstract}

Kata kunci: Pengembangan, LKS, Guided Discovery Learning, Statistika

Copyright (c) 2021 Faradila Nur Sabrina, Rustanto Rahardi

$\triangle$ Corresponding author: Faradila Nur Sabrina

Email Address: faradila.nur.1603116@students.um.ac.id.com (Jl. Semarang No. 5, Sumbersari, Malang)

Received 16 July 2021, Accepted 28 July 2021, Published 09 August 2021

\section{PENDAHULUAN}

Sesuai dengan anjuran pemerintah melalui Kementerian Pendidikan dan Kebudayaan (Kemendikbud) terkait dilaksanakannya proses Kegiatan Belajar Mengajar (KBM) dengan menggunakan sistem dalam jaringan (daring) berdasarkan "Surat Edaran Mendikbud No.4 Tahun 2020 tentang Pelaksanaan Kebijakan dan Pendidikan dalam Masa Darurat Penyebaran Corona Virus Desease (COVID19)”. Kegiatan belajar dan mengajar semua siswa mulai dari Sekolah Dasar hingga Universitas terpaksa harus dihentikan untuk sementara waktu dan dilanjutkan dengan pembelajaran daring (Wijaya dkk., 2020). Pelaksanaan pembelajaran daring yang dilaksanakan di tengah pandemi ini memanfaatkan berbagai media pembelajaran secara jarak jauh. Google classroom, google form, whatsapp, quipper school, zoom merupakan beberapa sarana yang sering digunakan sebagai alat bantu pelaksanaan pembelajaran daring. Pemanfaatan sarana-sarana online tersebut dilakukan secara maksimal menghindari terjadinya penyebaran dan penularan wabah COVID-19. Pelaksanaan pembelajaran yang dilakukan secara online merupakan tantangan baru bagi guru dan siswa karena salah satunya pembelajaran online rentan membuat siswa 
Pengembangan LKS Berbasis Guided Discovery Learning pada Materi Statistika Kelas VIII SMP, Faradila Nur Sabrina, Rustanto Rahardi

mengalami kebosanan (Yuzulia, 2021). Sehingga variasi-variasi pembelajaran yang dirasakan perlu pada saat pembelajaran tatap muka di kelas secara langsung juga perlu dilakukan pada saat pembelajaran daring. Beberapa variasi yang dapat dilakukan pada saat pembelajaran daring adalah penggunaan metode dan media pembelajaran yang tepat sehingga siswa merasa bersemangat dan tidak bosan ketika KBM (Wuarlela, 2020).

Hasil wawancara secara non formal kepada salah seorang siswa adalah siswa mengaku kurang bersemangat dalam pembelajaran matematika secara daring karena pola pembelajaran yang dilakukan oleh gurunya selalu tetap yaitu penggunaan aplikasi whatsapp untuk membagikan link video mengenai penjelasan konsep, kemudian siswa diminta untuk mencatat hal-hal penting yang terdapat pada video, dan dilanjut mengerjakan soal yang telah diberikan sebagai tugas untuk pertemuan pada hari tersebut. Wawancara juga dilakukan dengan salah seorang guru matematika SMP diketahui bahwa pembelajaran yang dilakukan selama ini terutama materi statistika, guru menggunakan buku paket BSE dan belum menggunakan media pembelajaran lain seperti LKS sebagai sumber belajar.

Statistika merupakan materi yang penting karena antara lain dapat membantu dalam pengambilan keputusan di kehidupan sehari-hari seperti pemilihan ketua OSIS berdasarkan suara yang terkumpul dan memprediksi suatu keadaan yang akan terjadi seperti prediksi banjir tahunan Jakarta (Songsore \& White, 2018). Kesulitan siswa dalam memahami konsep statistika menurut penelitian yang dilakukan oleh Kartika Dewi et al. (2020) antara lain adalah kesulitan menentukan rata-rata dari suatu data dan kesulitan menganalisis data. Hal tersebut disebabkan beberapa faktor antara lain siswa belum memahami konsep dasar statistika. Oleh karena itu perlu dilakukan pembelajaran yang dapat meningkatkan pemahaman siswa terhadap materi statistika.

Menurut Surachman (1998: 46) LKS merupakan lembaran yang mempunyai tujuan untuk membantu membimbing siswa ketika kegiatan pembelajaran secara terarah (guided discovery activities). Lembar Kerja Siswa yaitu bahan ajar yang sudah disesuaikan dengan kompetensi dasar yang akan dicapai, dilengkapi dengan arahan dan pertanyaan terstruktur dengan tujuan agar siswa dapat mempelajarinya secara mandiri (Majid, 2011: 176). LKS digunakan untuk meningkatkan keterlibatan siswa dalam kegiatan belajar dan membimbing siswa dalam memahami konsep (Hamdani, 2011: 74). Menurut penelitian yang dilakukan oleh Ivana Devi Astuti (2016) menyatakan bahwa Lembar Kerja Siswa (LKS) efektif meningkatkan pemahaman matematika siswa. Menurut Ermi (2016) LKS merupakan suatu alat yang mempermudah guru maupun siswa dalam kegiatan belajar mengajar. LKS berisi tahapan-tahapan untuk menemukan konsep melalui aktivitasnya secara mandiri maupun kelompok.

Tuntutan kompetensi yang terdapat pada Kurikulum 2013 adalah menekankan pada keaktifan siswa dalam menemukan pemahaman dan penyelesaian masalah. Oleh karena itu, perlu dilakukan model pembelajaran yang berpusat pada siswa (student centered learning). Berdasarkan Kementrian Pendidikan dan Kebudayaan Republik Indonesia Nomor 65 Tahun 2013 tentang standar proses, model pembelajaran yang disarankan salah satunya adalah model pembelajaran Discovery Learning. Discovery Learning adalah model pembelajaran yang mengembangkan cara belajar siswa secara aktif menemukan dan menyelidiki 
konsep maupun prinsip secara mandiri sehingga pengalaman yang diperloleh akan lebih bermakna bagi siswa (Hosnan, 2014: 282). Menurut Prasetyo dkk. (Suprihatiningrum, 2013: 245) Discovery Learning terbagi menjadi dua, yaitu free discovery (penemuan bebas) dan guided discovery (penemuan terbimbing). Guided discovery lebih banyak digunakan karena menggunakan petunjuk-petunjuk yang terarah untuk mencapai tujuan pembelajaran yang telah ditetapkan.

Model pembelajaran Guided Discovery Learning (Penemuan Terbimbing) merupakan model pembelajaran yang berpusat pada siswa dengan teknik menerka, menggunakan, menyelidiki, menarik kesimpulan, serta memungkinkan guru membimbing siswa dalam menggunakan ide, konsep, dan keterampilan yang dimiliki untuk menemukan pengetahuan yang baru (Pardede dkk., 2016). Dengan model pembelajaran ini, siswa dapat menemukan suatu konsep secara mandiri dengan bimbingan yang diberikan oleh guru sehingga siswa akan lebih mudah menyelesaikan permasalahan yang berhubungan dengan konsep yang siswa temukan. Karena dengan menemukan sendiri suatu konsep, siswa akan lebih mudah memahami dan mengingat konsep tersebut (Maya, 2019). Tahapan model pembelajaran Guided Discovery Learning menurut Ahmadi dan Prasetyo dalam (Ilahi, 2012) yaitu: (1) Simulasi; (2) Merumuskan Hipotesis; (3) Mengumpulkan Data; (4) Mengolah Data; (5) Verifikasi; (6) Menyimpulkan. Tahapan model pembelajaran Guided Discovery Learning adalah sebagai berikut.

1. Simulasi

Guru mengajukan pertanyaan, meminta siswa mengamati suatu bacaan, atau mendengarkan uraian yang memuat permasalahan.

2. Merumuskan Hipotesis

Siswa melakukan identifikasi masalah kemudian guru meminta siswa untuk menuliskan hasil identifikasi berupa pernyataan hipotesis.

3. Mengumpulkan Data

Guru memberikan kesempatan kepada siswa untuk mengumpulkan informasi sebanyak-banyaknya dari berbagai sumber dan menghubungkan dengan pengetahuan yang telah dimiliki sebelumnya untuk menyelesaikan permasalahan yang dihadapi.

4. Mengolah Data

Informasi yang diperoleh dari tahap mengumpulkan data akan diolah untuk menyelesaikan permasalahan yang dihadapi.

5. Verifikasi

Siswa melakukan pemeriksaan pernyataan hipotesis yang telah dibuat berdasarkan hasil dari mengolah data, apakah bisa terjawab dan terbukti dengan baik sehingga memiliki hasil yang memuaskan.

6. Menyimpulkan

Siswa membuat kesimpulan dan generalisasi mengenai konsep menggunakan bahasanya sendiri.

Dari hasil observasi dan wawancara yang telah dilakukan, peneliti menyimpulkan bahwa perlu adanya variasi pembelajaran yang meningkatkan ketertarikan siswa terhadap pembelajaran matematika daring pada materi Statistika yaitu pengembangan media pembelajaran berupa LKS dengan tahapan Guided 
Pengembangan LKS Berbasis Guided Discovery Learning pada Materi Statistika Kelas VIII SMP, Faradila Nur Sabrina, Rustanto Rahardi

Discovery Learning, dimana kegiatan yang dilakukan dalam LKS tersebut berpusat kepada siswa dan menuntun siswa untuk menemukan serta menguasai konsep-konsep Statistika secara mandiri.

Pengembangan bahan ajar LKS dengan tahapan Guided Discovery Learning telah dilakukan sebelumnya oleh Septiana (2018) dengan hasil penelitian yaitu LKS yang telah dikembangkan dengan model penemuan terbimbing efektif terhadap kemampuan pemecahan masalah matematis siswa. Penelitian lain mengenai pengembangan LKS dengan basis Guided Discovery Learning yang dilakukan oleh Noviafitri (2016) dengan hasil penelitian yaitu LKS yang dikembangkan memiliki efek potensial terhadap hasil belajar pada ranah kognitif, afektif, dan psikomotorik. Peneliti belum menemui pengembangan LKS berbasis Guided Discovery Learning pada materi Statistika kelas VIII SMP/MTs. Berdasarkan latar belakang tersebut, maka penelitian ini memiliki tujuan untuk mengembangkan LKS berbasis Guided Discovery Learning pada materi Statistika kelas VIII.

\section{METODE}

\section{Rancangan Penelitian}

Penelitian ini termasuk dalam model Research and Development (R\&D) yaitu penelitian dan pengembangan dimana penelitian ini menghasilkan suatu produk yang kemudian akan diuji keefektifannya (Sugiyono, 2008). Penelitian ini mengembangkan produk berupa Lembar Kerja Siswa (LKS) matematika pada siswa kelas VIII materi Statistika. Dalam pengembangannya, penelitian ini menggunakan model pengembangan yang mengacu pada model Plomp (2010: 16) dengan tahapan ditunjukkan pada Gambar 1.

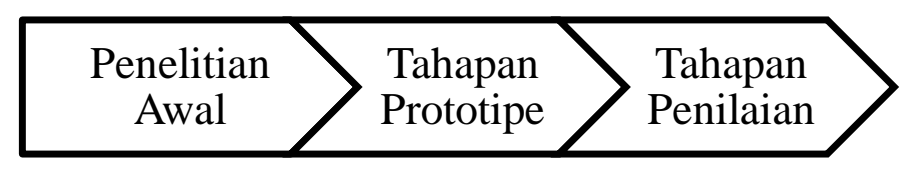

Gambar 1. Tahapan Penelitian Plomp

\section{Data Penelitian}

Penelitian ini dilaksanakan di SMP Nasional Malang yang terletak di Jl. S. Supriadi No.50, Bandungrejosari, Kec. Sukun, Kota Malang, Jawa Timur pada bulan Juni 2021 dengan subjek penelitian 10 siswa SMP kelas VIII SMP Nasional Malang. Subjek penelitian dipilih 10 siswa dari total 31 siswa dengan pertimbangan jarak rumah ke sekolah, karena produk diberikan berupa print-out di sekolah dan pelaksanaan pembelajaran dilakukan secara daring. Subjek yang dipilih juga sudah mewakili tiap-tiap tingkat kemampuan rendah, sedang, dan tinggi.

Tabel 1. Penjelasan Data, Instrumen, dan Teknik Pengumpulan Data

\begin{tabular}{|l|c|c|c|}
\hline Penilaian & Instrumen & Data yang diamati & Sumber Data \\
\hline Kevalidan & Lembar Validasi & LKS, RPP, Soal Tes & Validator ahli (Dosen \\
& & Formatif, Lembar & Matematika) dan \\
& & Observasi Kegiatan & validator praktisi \\
& & Guru, Angket Respon & (Guru Matematika) \\
\hline
\end{tabular}




\begin{tabular}{|c|c|c|c|}
\hline Kepraktisan & $\begin{array}{c}\text { Lembar Observasi } \\
\text { Kegiatan Guru, } \\
\text { Angket Respon } \\
\text { Siswa, dan Angket } \\
\text { Respon Guru. }\end{array}$ & $\begin{array}{c}\text { Siswa, dan Angket } \\
\text { Respon Guru. } \\
\text { Kegiatan guru model, } \\
\text { respon siswa, dan } \\
\text { respon guru. }\end{array}$ & $\begin{array}{c}\text { Guru model dan } \\
\text { subjek penelitian }\end{array}$ \\
\hline Keefektivan & Tes Formatif & Nilai siswa & Subjek penelitian \\
\hline
\end{tabular}

\section{Analisis Data}

Adapun teknik analisis data yang digunakan dalam penelitian ini dijelaskan sebagai berikut.

\section{Analisis Kevalidan}

Dalam uji kevalidan, peneliti menggunakan skala Likert dan kolom kritik dan saran. Skala Likert dideskripsikan pada Tabel 2 berikut.

Tabel 2. Deskripsi Skala Likert

\begin{tabular}{|c|c|}
\hline Skor & Keterangan \\
\hline 4 & Sangat baik \\
\hline 3 & Baik \\
\hline 2 & Kurang baik \\
\hline 1 & Tidak baik \\
\hline
\end{tabular}

(Adaptasi: Likert, 1932)

Skor yang diperoleh dari lembar validasi dengan skala Likert akan diolah menggunakan rumus analisis persentase kevalidan sebagai berikut.

$$
V=\frac{T S e}{T S h} \times 100 \%
$$

Keterangan:

V : Persentase validitas

TSe : Total skor empirik

TSh : Total skor maksimal

Setelah dilakukan analisis, hasil yang diperoleh akan ditafsirkan dan disimpulkan berdasarkan kriteria kevalidan pada Tabel 3 berikut.

Tabel 3. Kriteria Hasil Validasi

\begin{tabular}{|c|c|c|}
\hline Rentang Nilai & Tingkat Kevalidan & Keterangan \\
\hline $81 \%-100 \%$ & Sangat Valid & Produk dapat digunakan tanpa adanya perbaikan \\
\hline $61 \%-80 \%$ & Valid & Produk dapat digunakan dengan perbaikan kecil \\
\hline $41 \%-60 \%$ & Kurang Valid & $\begin{array}{c}\text { Produk baiknya tidak digunakan karena perlu } \\
\text { perbaikan besar }\end{array}$ \\
\hline $21 \%-40 \%$ & Tidak Valid & Produk tidak boleh digunakan \\
\hline $0 \%-20 \%$ & Sangat Tidak Valid & Produk tidak boleh digunakan \\
\hline
\end{tabular}

(Adaptasi: Akbar, 2013) 
Pengembangan LKS Berbasis Guided Discovery Learning pada Materi Statistika Kelas VIII SMP, Faradila Nur Sabrina, Rustanto Rahardi

\section{Analisis Kepraktisan}

Dalam analisis kepraktisan, peneliti menggunakan data yang diperoleh dari angket respon siswa setelah menggunakan produk. Data yang diperoleh akan dianalisis menggunakan rumus analisis persentase kepraktisan sebagai berikut.

$$
P=\frac{T S e}{T S h} \times 100 \%
$$

Keterangan:

$\mathrm{P}$

: Persentase kepraktisan

TSe $\quad$ : Total skor empirik

TSh : Total skor maksimal

Setelah dilakukan analisis, hasil yang diperoleh akan ditafsirkan dan disimpulkan berdasarkan kriteria kepraktisan pada Tabel 4 berikut.

Tabel 4 Kriteria Hasil Kepraktisan

\begin{tabular}{|c|c|}
\hline Rentang Nilai & Tingkat Kepraktisan \\
\hline $81 \%-100 \%$ & Sangat Praktis \\
\hline $61 \%-80 \%$ & Praktis \\
\hline $41 \%-60 \%$ & Kurang Praktis \\
\hline $21 \%-40 \%$ & Tidak Praktis \\
\hline $0 \%-20 \%$ & Sangat Tidak Praktis \\
\hline
\end{tabular}

(Adaptasi: Akbar, 2013)

Berdasarkan kriteria hasil kepraktisan produk di atas, produk dinyatakan praktis ketika produk memiliki nilai kepraktisan pada rentang $61 \%$ sampai $100 \%$.

\section{Analisis Keefektifan}

Dalam analisis kefeektifan, peneliti menggunakan data yang diperoleh dari hasil tes formatif siswa. Keefektifan media pembelajaran dilihat dari hasil belajar siswa menggunakan LKS yang diuji cobakan. LKS dalam penelitian ini dikatakan efektif ketika $\geq 70 \%$ subjek uji coba sudah mencapai KKM (Kriteria Ketuntasan Minimal) yaitu 70 (Hobri, 2010).

\section{HASIL DAN DISKUSI}

\section{Hasil Penelitian}

\section{Preliminary investigation (penelitian awal)}

Peneliti mengumpulkan data penelitian awal ini dengan melakukan studi kepustakaan dan wawancara. Peneliti melakukan studi kepustakaan dengan mengkaji jurnal maupun skripsi mengenai kesulitan yang terjadi pada siswa saat mempelajari materi Statistika, mengidentifikasi KI dan KD yang dilanjutkan dengan perumusan Indikator Pencapaian Kompetensi dan Tujuan Pembelajaran. Wawancara dilakukan secara non formal pada seorang siswa dan seorang guru mata pelajaran matematika. Berikut beberapa hasil dari kegiatan penelitian awal berupa pengembangan KD menjadi Indikator Pencapaian Kompetensi dan Tujuan Pembelajaran. 


\section{Kompetensi Dasar}

3.10 Menganalisis data berdasarkan terkelompok data, nilai rata-rata, median, modus, dan sebaran data untuk mengambil kesimpulan, membuat keputusan, dan membuat prediksi.

\section{Indikator Pencapaian Kompetensi}

3.10.1 Menyebutkan syarat data untuk menentukan nilai rata-rata

3.10.2 Menyebutkan syarat data untuk menentukan modus

\section{Tujuan Pembelajaran}

3.10.1.1 Melalui contoh pengolahan data tersebar, siswa dapat menyebutkan syarat data untuk menentukan nilai rata-rata dari suatu data yang tersebar dengan tepat.

3.10.1.2 Melalui contoh pengolahan data terkelompok, siswa dapat menyebutkan syarat data untuk menentukan nilai rata-rata dari suatu terkelompok data dengan tepat.

3.10.2.1 Melalui pengamatan terhadap data tersebar, siswa dapat menyebutkan syarat data tersebut untuk menentukan nilai modus dari suatu data yang tersebar dengan tepat.

3.10.2.2 Melalui pengamatan terhadap data terkelompok, siswa dapat menyebutkan syarat data untuk menentukan nilai modus dari suatu data terkelompok dengan tepat.

\section{Prototype phase (Tahapan Prototipe)}

Dalam tahapan prototipe ini, peneliti merancang instrumen kevalidan, kepraktisan, dan keefektivan LKS, format penulisan LKS, dan desain awal LKS. Setelah disesuaikan dengan format LKS menurut Prastowo (2011), format LKS yang dikembangkan meliputi:

1. Halaman Sampul berisi: Judul Materi; Kelas/Semester.

2. Identitas LKS yang lain yaitu: Kompetensi Dasar; Indikator; Materi Pokok.

3. Proses Belajar berisi: Petunjuk umum penggunaan LKS; Pendahuluan; Kegiatan Inti; Penutup.

4. Kolom/ruang kosong tempat untuk menuangkan hasil atau ide siswa.

Dalam tahapan ini juga dirumuskan LKS terdiri dari beberapa kegiatan pembelajaran yang menggunakan langkah-langkah Guided Discovery Learning. Berikut Gambar 2 (a), (b), (c), dan (d) yang merupakan tampilan LKS dengan langkah-langkah Guided Discovery Learning yang telah dikembangkan peneliti. 
Pengembangan LKS Berbasis Guided Discovery Learning pada Materi Statistika Kelas VIII SMP, Faradila Nur Sabrina, Rustanto Rahardi

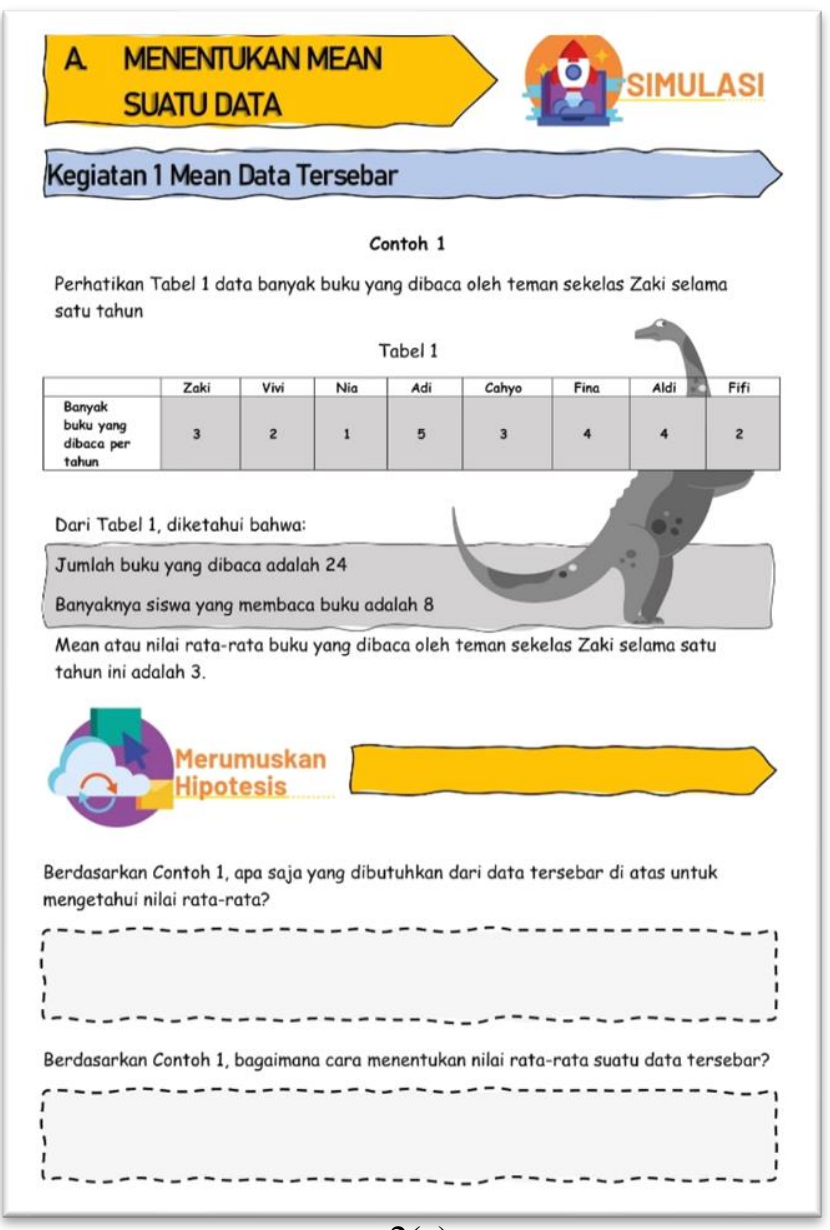

2(a)

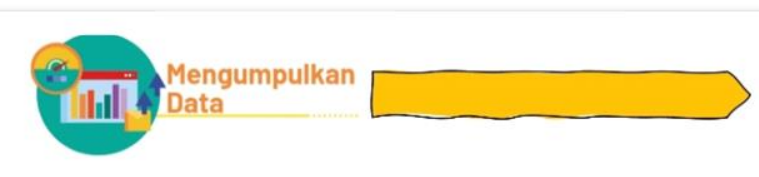

Perhatikan lagi Tabel 1. Kemudian, jawablah pertanyaan-pertanyaan berikut dengan benar.

1. Jumlahkan seluruh bilangan yang menyatakan banyak buku.

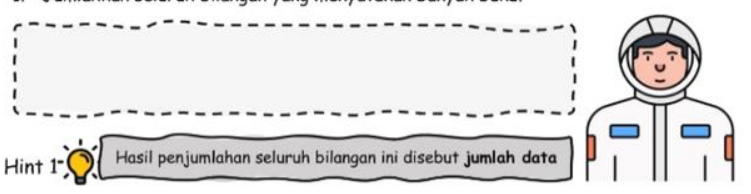

2. Berapa jumlah anak yang membaca buku?
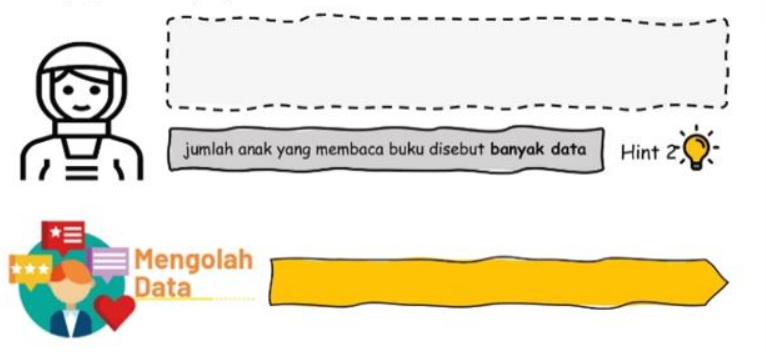

3. Bagilah hasil penjumlahan seluruh bilangan yang menyatakan banyak buku dengan jumlah anak yang terdaftar membaca buku.

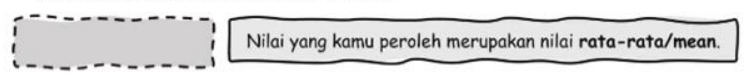

4. Berdasarkan hint 1 dan 2 ,

bagaimana cara memperoleh nilai rata-rata/mean dari suatu data tersebar?

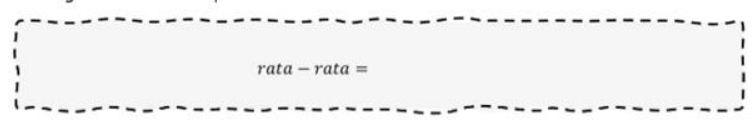

2(b)

5. Jika jumlah data dapat dituliskan dengan $x_{1}+x_{2}+x_{3}+x_{4}+\cdots+x_{n}$ dan banyak data adalah $n$, Rumus mencari nilai rata-rata $(\bar{x})$ suatu data tersebar adalah

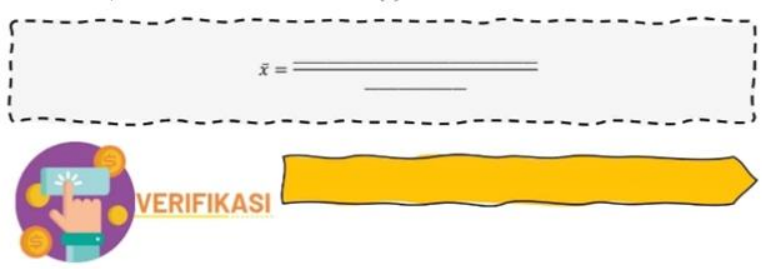

Mari melakukan verifikasi dari hipotesis yang telah kamu buat. Coba bandingkan apakah hipotesismu sudah sesuai atau tidak.

Informasi yang perlu diketahui untuk mencari nilai rata-rata suatu data tersebar adalah jumlah data dan banyak data.

Nilai rata-rata suatu data tersebar dapat ditemukan dengan cara jumlah data dibagi dengan banyak data.

Rumus mencari nilai rata-rata suatu data tersebar adalah

$$
\bar{x}=\frac{x_{1}+x_{2}+x_{3}+x_{4}+\cdots+x_{n}}{n}
$$

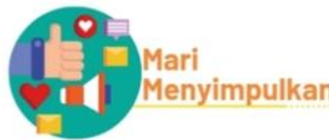

Bagaimana kesimpulan hipotesismu setelah melakukan verifikasi? Bagaimana cara menentukan nilai rata-rata dari suatu data tersebar?

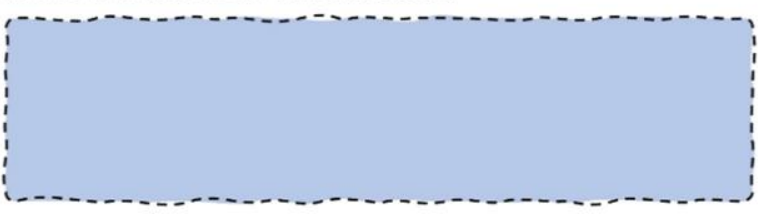




\section{Test, Evaluation, And Revision (Tahapan Uji Coba, Evaluasi, Dan Revisi)}

1. Validasi Produk

Uji validasi ini dilakukan untuk menilai LKS yang telah dibuat ini layak diberikan kepada siswa berdasarkan poin-poin pada lembar validasi. Lembar validasi ini meliputi lembar validasi LKS, RPP, Soal Tes Formatif, Lembar Observasi Kegiatan Guru, Angket Respon Siswa, dan Angket Respon Guru. Hasil Validasi LKS ditampilkan pada Tabel 4.

Tabel 4 Data Hasil Validasi LKS

\begin{tabular}{|c|c|c|c|c|}
\hline \multirow{3}{*}{ No. } & \multirow{3}{*}{ Aspek } & \multicolumn{3}{|c|}{ Skor } \\
\hline & & \multicolumn{2}{|c|}{ V1 } & \multirow[t]{2}{*}{$\mathbf{V 2}$} \\
\hline & & SR & $\mathbf{R}$ & \\
\hline \multirow[t]{5}{*}{1.} & \multicolumn{4}{|l|}{ Komponen LKS } \\
\hline & $\begin{array}{l}\text { a. Kelengkapan komponen LKS meliputi judul } \\
\text { kegiatan, petunjuk kerja, alat dan bahan jika } \\
\text { diperlukan. }\end{array}$ & 4 & 4 & 4 \\
\hline & $\begin{array}{l}\text { b. Identitas LKS memuat: nama mata pelajaran, } \\
\text { kelas/semester, materi, alokasi waktu, dan } \\
\text { indikator pencapaian kompetensi. }\end{array}$ & 2 & 3 & 3 \\
\hline & $\begin{array}{l}\text { c. Komponen identitas LKS tidak menyimpang } \\
\text { dari RPP yang telah dirancang. }\end{array}$ & 2 & 4 & 4 \\
\hline & $\begin{array}{l}\text { d. Disediakan tabel/kolom untuk hasil } \\
\text { pengamatan/pengukuran siswa. }\end{array}$ & 3 & 4 & 4 \\
\hline \multirow[t]{5}{*}{2.} & \multicolumn{4}{|l|}{ Kegiatan Pembelajaran LKS } \\
\hline & $\begin{array}{l}\text { a. Petunjuk penggunaan LKS berisi informasi } \\
\text { prosedur belajar yang harus dilakukan oleh } \\
\text { siswa. }\end{array}$ & 4 & 4 & 4 \\
\hline & $\begin{array}{ll}\text { b. } & \text { Kegiatan Pendahuluan } \\
\text { Memuat gambaran berupa masalah sehari-hari } \\
\text { yang berhubungan dengan statistika. }\end{array}$ & 4 & 4 & 4 \\
\hline & $\begin{array}{l}\text { c. Kegiatan Inti } \\
\text { Kegiatan inti disajikan dalam bentuk kegiatan } \\
\text { belajar yang menggambarkan proses belajar } \\
\text { bertahap dan berlanjut. }\end{array}$ & 4 & 4 & 4 \\
\hline & $\begin{array}{ll}\text { d. } & \text { Kegiatan Penutup } \\
\text { Mengadakan evaluasi tentang materi yang baru } \\
\text { dipelajari. }\end{array}$ & 4 & 4 & 4 \\
\hline \multirow[t]{5}{*}{3.} & \multicolumn{4}{|c|}{ Kesesuaian dengan Pembelajaran Berbasis Guided Discovery Learning } \\
\hline & $\begin{array}{l}\text { a. Susunan aktivitas sesuai dengan metode } \\
\text { Guided Discovery Learning, yaitu tahap } \\
\text { Simulasi, Merumuskan Hipotesis, } \\
\text { Mengumpulkan Data, Mengolah Data, } \\
\text { Verifikasi, dan Menyimpulkan. }\end{array}$ & 3 & 4 & 4 \\
\hline & $\begin{array}{l}\text { b. Kegiatan pada tahap Simulasi sesuai dengan } \\
\text { teori penjabaran aktivitas simulasi. }\end{array}$ & 3 & 4 & 4 \\
\hline & $\begin{array}{l}\text { c. Kegiatan pada tahap Merumuskan Hipotesis } \\
\text { sesuai dengan teori penjabaran aktivitas } \\
\text { merumuskan hipotesis. }\end{array}$ & 2 & 4 & 4 \\
\hline & 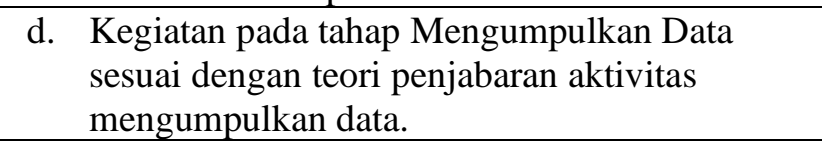 & 2 & 4 & 4 \\
\hline
\end{tabular}


Pengembangan LKS Berbasis Guided Discovery Learning pada Materi Statistika Kelas VIII SMP, Faradila Nur Sabrina, Rustanto Rahardi

\begin{tabular}{|c|c|c|c|c|}
\hline & $\begin{array}{l}\text { e. Kegiatan pada tahap Mengolah Data sesuai } \\
\text { dengan teori penjabaran aktivitas mengolah } \\
\text { data. }\end{array}$ & 2 & 4 & 4 \\
\hline & $\begin{array}{l}\text { f. Kegiatan pada tahap Verifikasi sesuai dengan } \\
\text { teori penjabaran aktivitas verifikasi. }\end{array}$ & 2 & 4 & 4 \\
\hline & $\begin{array}{l}\text { g. Kegiatan pada tahap Menyimpulkan sesuai } \\
\text { dengan teori penjabaran aktivitas } \\
\text { menyimpulkan. }\end{array}$ & 2 & 4 & 4 \\
\hline & $\begin{array}{l}\text { h. Aktivitas pada LKS menuntut siswa untuk } \\
\text { menemukan konsep dan memahami konsep } \\
\text { tentang Statistika. }\end{array}$ & 2 & 4 & 3 \\
\hline 4. & \multicolumn{4}{|l|}{ Bahasa dan Tampilan } \\
\hline & a. $\quad$ Bahasa yang digunakan komunikatif. & 2 & 4 & 3 \\
\hline & $\begin{array}{l}\text { b. Bahasa yang digunakan tidak menimbulkan } \\
\text { makna ganda. }\end{array}$ & 2 & 3 & 3 \\
\hline & c. Ukuran dan jenis font yang digunakan tepat. & 4 & 3 & 4 \\
\hline & $\begin{array}{l}\text { d. Desain tampilan LKS menarik minat belajar } \\
\text { siswa. }\end{array}$ & 4 & 3 & 3 \\
\hline & Skor Total & 57 & 76 & 75 \\
\hline & Persentase Skor (\%) & 71,25 & 95 & 93,75 \\
\hline & Kategori Kevalidan & $\mathrm{V}$ & SV & SV \\
\hline
\end{tabular}

Keterangan:

SR = Hasil Uji Validasi oleh Validator 1 Sebelum Revisi

$\mathrm{R}=$ Hasil Uji Validasi oleh Validator 1 Setelah Revisi

V1 = Validator Ahli Dosen FMIPA

V2 = Validator Praktisi Guru Matematika

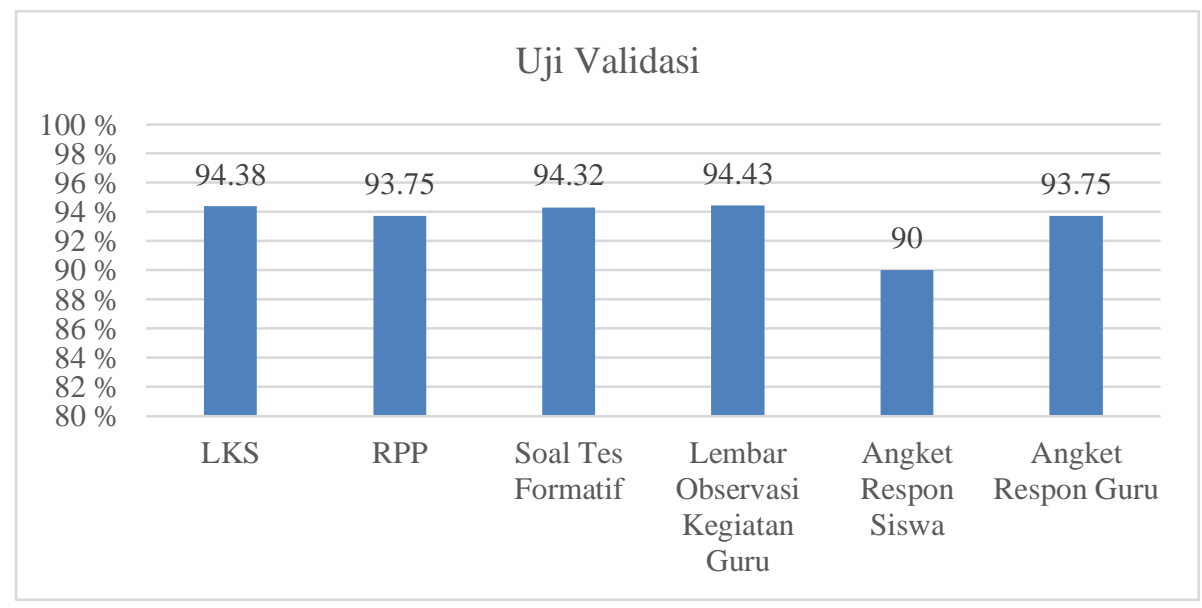

Gambar 2. Hasil Uji Kevalidan

2. Uji Coba Produk

Setelah adanya uji validasi dan dilakukan revisi, LKS akan diujicobakan pada subjek penelitian. Subjek penelitian produk adalah 10 siswa SMP kelas VIII SMP Nasional Malang dan memiliki kemampuan 
yang berbeda-beda. Kegiatan uji coba dan pengumpulan data oleh 10 siswa dilakukan selama 4 pertemuan. Data tersebut digunakan sebagai penilaian keefektivan dan kepraktisan produk pengembangan.

3. Uji Kepraktisan

Uji Kepraktisan dilakukan untuk menilai antara lain seberapa mudah LKS dalam memberikan informasi dan keterlaksanaan pembelajaran dengan tahapan Guided Discovery Learning. Uji kepraktisan LKS dilakukan oleh siswa dan guru menggunakan angket respon siswa, angket respon guru, dan observasi kegiatan guru. Uji kepraktisan menggunakan angket respon siswa dengan hasil rata-rata 82,19\%, angket respon guru dengan hasil 92,5\%, dan observasi kegiatan guru yang dilakukan sebanyak 4 kali dengan hasil rata-rata $93,31 \%$ yang dapat dilihat pada tabel 5 .

Tabel 5 Data Hasil Observasi Guru

\begin{tabular}{|c|c|c|c|c|c|c|}
\hline \multirow{2}{*}{ No } & \multirow{2}{*}{ Aspek } & \multicolumn{4}{|c|}{ Skor Tiap Indikator } & \multirow{2}{*}{$\begin{array}{l}\text { Persentase } \\
\text { Indikator }\end{array}$} \\
\hline & & P1 & $\mathrm{P} 2$ & P3 & $\mathrm{P} 4$ & \\
\hline \multirow[t]{7}{*}{1} & \multicolumn{6}{|l|}{ KEGIATAN PENDAHULUAN } \\
\hline & $\begin{array}{l}\text { a. Guru mengorganisasikan kelas untuk } \\
\text { belajar }\end{array}$ & 3 & 3 & 3 & 3 & $75 \%$ \\
\hline & b. Guru melakukan presensi & 3 & 3 & 3 & 3 & $75 \%$ \\
\hline & $\begin{array}{l}\text { c. Guru menyampaikan topik dan tujuan } \\
\text { pembelajaran }\end{array}$ & 3 & 3 & 3 & 3 & $75 \%$ \\
\hline & $\begin{array}{l}\text { d. Guru menyampaikan apersepsi dengan } \\
\text { bertanya kepada siswa terkait materi } \\
\text { prasyarat yang telah dipelajari oleh } \\
\text { siswa sebelumnya. }\end{array}$ & 4 & 4 & 4 & 4 & $100 \%$ \\
\hline & $\begin{array}{l}\text { e. Guru memberikan motivasi dengan } \\
\text { memberikan masalah yang berkaitan } \\
\text { dengan materi pada LKS }\end{array}$ & 4 & 4 & 4 & 4 & $100 \%$ \\
\hline & $\begin{array}{l}\text { f. Guru meminta siswa untuk membaca } \\
\text { petunjuk pengerjaan }\end{array}$ & 3 & 4 & 3 & 4 & $87,5 \%$ \\
\hline 2 & \multicolumn{6}{|l|}{ KEGIATAN INTI } \\
\hline & $\begin{array}{l}\text { a. Guru meminta siswa untuk melaksanakan } \\
\text { kegiatan Simulasi dengan cara membaca } \\
\text { cerita/informasi pada LKS }\end{array}$ & 4 & 4 & 4 & 4 & $100 \%$ \\
\hline & $\begin{array}{l}\text { b. Guru meminta siswa untuk melaksanakan } \\
\text { kegiatan Merumuskan Hipotesis dengan } \\
\text { menuliskan hipotesis setelah melakukan } \\
\text { kegiatan Simulasi. }\end{array}$ & 4 & 4 & 4 & 4 & $100 \%$ \\
\hline & $\begin{array}{ll}\text { c. Guru meminta siswa untuk melaksanakan } \\
\text { kegiatan Mengupulkan Data dengan } \\
\text { menjawab pertanyaan dan mencari } \\
\text { informasi yang dibutuhkan pada LKS. }\end{array}$ & 4 & 4 & 4 & 4 & $100 \%$ \\
\hline & $\begin{array}{l}\text { d. Guru meminta siswa untuk melaksanakan } \\
\text { kegiatan Mengolah Data dengan cara } \\
\text { menjawab pertanyaan-pertanyaan pada } \\
\text { LKS. }\end{array}$ & 4 & 4 & 4 & 4 & $100 \%$ \\
\hline & $\begin{array}{l}\text { e. Guru meminta siswa untuk melaksanakan } \\
\text { kegiatan Verifikasi dengan cara } \\
\text { memahami dan mengaitkan hipotesis } \\
\text { yang telah dibuat sudah sesuai atau tidak. }\end{array}$ & 4 & 4 & 4 & 4 & $100 \%$ \\
\hline & $\begin{array}{l}\text { f. Guru meminta siswa untuk melaksanakan } \\
\text { kegiatan Menyimpulkan dengan cara }\end{array}$ & 4 & 4 & 4 & 4 & $100 \%$ \\
\hline
\end{tabular}


Pengembangan LKS Berbasis Guided Discovery Learning pada Materi Statistika Kelas VIII SMP, Faradila Nur Sabrina, Rustanto Rahardi

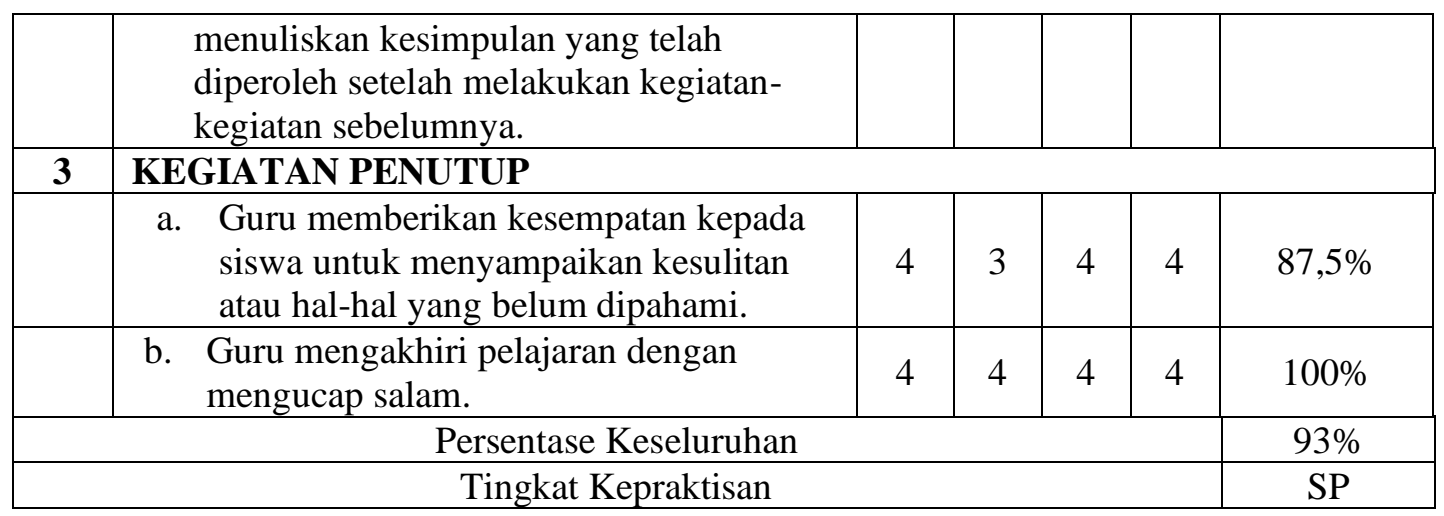

Keterangan:

P1 = Pertemuan Pertama

P3 = Pertemuan Ketiga

$\mathrm{P} 2$ = Pertemuan Kedua

P4 = Pertemuan Keempat

\section{KESIMPULAN}

Berdasarkan hasil penelitian dan pembahasan di atas, LKS materi Statistika berbasis Guided Discovery Learning untuk kelas VIII SMP Nasional Malang dinyatakan valid, praktis, dan efektif. LKS yang dikembangkan dinyatakan valid berdasarkan uji validasi oleh validator dengan hasil 93,75\%. Setelah dilakukan uji validasi, LKS diujicobakan kepada subjek penelitian dan dinyatakan praktis berdasarkan hasil angket respon siswa yaitu $82,19 \%$ dan angket respon guru yaitu 93,31\%. LKS juga dinyatakan efektif berdasarkan hasil tes formatif subjek penelitian, terdapat $80 \%$ siswa mendapat nilai di atas KKM.

Bagi pengembangan LKS berbasis Guided Discovery Learning selanjutnya disarankan untuk mengembangkan pada materi-materi yang lain dan LKS yang sudah dikembangkan dapat diakses dan dikerjakan langsung secara online agar lebih mudah dan praktis.

\section{UCAPAN TERIMA KASIH}

Ucapan terimakasih saya sampaikan kepada Dosen Pembimbing Skripsi Bapak Rustanto Rahardi, Dosen Validator Produk Bapak Hendro Permadi, dan Guru Matematika SMP Nasional Malang Ibu Ira Ariesta Bakti yang telah membantu proses penyusunan artikel ini.

\section{REFERENSI}

Akbar, S. (2013). Instrumen Perangkat Pembelajaran. PT Remaja Posdakarya.

Ermi, N. (2017). Penggunaan Media Lembar Kerja Siswa (LKS) dalam Meningkatkan Hasil Belajar Sosiologi Siswa Kelas XI SMAN 15 Pekanbaru. Jurnal Pendidikan Universitas Riau, 8. https://garuda.ristekbrin.go.id/documents/detail/1404578

Hamdani. (2011). Strategi Belajar Mengajar. Pustaka Setia.

Hobri. (2010). Metodologi Penelitian Pengembangan. Pena Salsabila.

Hosnan, M. (2014). Pendekatan saintifik dan kontekstual dalam pembelajaran abad 21: Kunci sukses implementasi kurikulum 2013. Ghalia Indonesia. 
Ilahi, M. T. (2012). Pembelajaran Discovery Strategy dan Mental Vocational Skill. DIVA Press.

Ivana Devi Astuti, B. (2016). Efektivitas Penggunaan Lembar Kerja Siswa pada Pembelajaran Matematika Pokok Bahasan Bilangan Bulat Ditinjau dari Hasil Belajar dan Pemahaman Siswa Kelas VII Compassion SMP JOANNES BOSCO Yogyakarta. Universitas Sanata Dharma.

Kartika Dewi, D., Sarah Khodijah, S., \& Sylviana Zanthy, L. (2020). Analisis Kesulitan Matematika Siswa SMP pada Materi Statistika. Jurnal Cendekia: Jurnal Pendidikan Matematika, 4(1), 1-7.

Kementrian Pendidikan dan Kebudayaan Republik Indonesia. (t.t.). Peraturan Menteri Pendidikan Dan Kebudayaan Republik Indonesia Nomor 65 Tahun 2013 Tentang Standar Proses Pendidikan Dasar Dan Menengah.

Likert, R. (1932). A Technique for The Measurement of Attitudes. New York University. https://legacy.voteview.com/pdf/Likert_1932.pdf

Majid, A. (2011). Perencanaan Pembelajaran. PT Remaja Rosdakarya.

Maya, Y. (2019). Penerapan Model Pembelajaran Guided Discovery Learning (GDL) untuk Meningkatkan Hasil Belajar pada Siswa SMPN 1 Bandar Baru. Universitas Islam Negeri Ar-Raniry.

Noviafitri, S. (2016). Pengembangan Lembar Kerja Siswa Berbasis Model Discovery Learning pada Pokok Bahasan Sudut Kelas VII. Universitas Sriwijaya.

Pardede, E., Motlan, \& Suyanti, R. D. (2016). Efek Model Pembelajaran Guided Discovery Berbasis Kolaborasi dengan Media Flash Terhadap Keterampilan Proses Sains dan Hasil Belajar Kognitif Tinggi Fisika Siswa SMA. Jurnal Pendidikan Fisika, 5 (1). http://jurnal.unimed.ac.id/2012/index.php/jpf

Plomp, T., \& Nieveen, N. M. (2010). An introduction to educational design research: Proceedings of the seminar conducted at the East China Normal University, Shanghai (PR China), November 23-26, 2007.

http://www.slo.nl/downloads/2009/Introduction_20to_20education_20design_20research.pdf/downl $\mathrm{oad}$

Septiana, R. (2018). Pengembangan LKPS dengan pendekatan Guided Discovery Learning dalam Kemampuan Memecahkan Masalah Berdasarkan Polya di SMP Negeri 11 Bandar Lampung. Universitas Islam Negeri Raden Intan.

Songsore, E., \& White, B. J. G. (2018). Students' Perceptions of the Future Relevance of Statistics After Completing an Online Introductory Statistics Course. Statistics Education Research Journal, 17(2)(International Association for Statistical Education (IASE/ISI)).

Sugiyono. (2008). Metode Penelitian Pendidikan: Pendekatan Kuantitatif, Kualitatif, dan R\&D. Alfabeta.

Suprihatiningrum, J. (2013). Strategi Pembelajaran: Teori dan Aplikasi. Ar-Ruzz Media.

Surachman. (1998). Pengembangan Bahan Ajar. Jurusan Pendidikan Biologi FMIPA IKIP.

Wijaya, T. T., Ying, Z., \& Suan, L. (2020). Gender and Self Regulated Learning During COVID-19 Pandemic in Indonesia. Jurnal Basicedu, 4(3), 725-732. https://doi.org/10.31004/basicedu.v4i3.422 
Pengembangan LKS Berbasis Guided Discovery Learning pada Materi Statistika Kelas VIII SMP, Faradila Nur Sabrina, Rustanto Rahardi

Wuarlela, M. (2020). Variasi Metode dam Media Pembelajaran Daring untuk Mengakomodasi Modalitas Belajar. ARBITRER: Jurnal Pendidikan Bahasa dan Sastra Indonesia, 2(2), 261-272. https://doi.org/10.30598/arbitrervol2no2hlm261-272

Yuzulia, I. (2021). The Challenges Of Online Learning During Pandemic: Students' Voice. Wanastra: Jurnal Bahasa dan Sastra, 12(1). https://doi.org/10.31294/w.v12i1 